Reproductive factors and risk of melanoma : a population-based cohort study

Stoer, N. C.

2019-08

Stoer , N C, Botteri , E, Ghiasvand, R, Busund, M , Vangen, S, Lund, E, Veierod, M B \& Weiderpass , E 2019 , ' Reproductive factors and risk of melanoma : a population-based cohort study ' , British Journal of Dermatology , vol. 181 , no. 2 , pp. 282-289 . https://doi.org/10.1111/bjd.17771

http://hdl.handle.net/10138/311475

https://doi.org/10.1111/bjd.17771

acceptedVersion

Downloaded from Helda, University of Helsinki institutional repository.

This is an electronic reprint of the original article.

This reprint may differ from the original in pagination and typographic detail.

Please cite the original version. 
MS NATHALIE C. ST ØER (Orcid ID : 0000-0001-8994-9332)

PROFESSOR MARIT B. B VEIER ØD (Orcid ID : 0000-0002-2083-2758)

Article type : Original Article

\title{
Reproductive factors and risk of melanoma: a population-based cohort study
}

\author{
Authors: N. C. Støer ${ }^{1}$, E. Botteri ${ }^{1,2}$, R. Ghiasvand ${ }^{3}$, M. Busund ${ }^{4}$, S. Vangen ${ }^{1,5}$, E. Lund ${ }^{4,6}$, M. B. \\ Veierø $\mathrm{d}^{3} *$ and E. Weiderpass $\mathrm{s}^{4,6,7,8 *}$ \\ ${ }^{*}$ Contributed equally
}

${ }^{1}$ Norwegian National Advisory Unit on Women's Health, Women's Clinic, Oslo University Hospital, Oslo, Norway

${ }^{2}$ Department of Bowel Cancer Screening, Cancer Registry of Norway, Institute of Population-Based Cancer Research, Oslo University Hospital, Oslo, Norway

${ }^{3}$ Oslo Centre for Biostatistics and Epidemiology, Department of Biostatistics, Institute of Basic Medical Sciences, University of Oslo, Oslo, Norway.

${ }^{4}$ Department of Community Medicine, University of Troms $\varnothing$, The Arctic University of Norway, Troms $\varnothing$, Norway.

${ }^{5}$ Institute of Clinical Medicine, University of Oslo, Oslo, Norway

${ }^{6}$ Department of Research, Cancer Registry of Norway, Institute of Population-Based Cancer Research, Oslo University Hospital, Oslo, Norway

${ }^{7}$ Department of Medical Epidemiology and Biostatistics, Karolinska Institutet, Stockholm, Sweden

${ }^{8}$ Genetic Epidemiology Group, Folkhälsan Research Center, Faculty of Medicine, University of Helsinki, Helsinki, Finland

Corresponding author:

Nathalie C. Støer

Address: Cancer Registry of Norway

Post box 5313 Majorstuen

Norway

Email: Nathalie.C.Stoer@kreftregisteret.no

Phone: +4722928934

Short title: Reproductive factors and risk of melanoma

Funding sources: R.G. was supported by a grant (project 6823329) from the Norwegian Cancer Society

Disclosures: None

This article has been accepted for publication and undergone full peer review but has not been through the copyediting, typesetting, pagination and proofreading process, which may lead to differences between this version and the Version of Record. Please cite this article as doi: $10.1111 /$ bjd. 17771

This article is protected by copyright. All rights reserved. 
Keywords: melanoma, reproductive factors, hormones, prospective cohort study, menstrual cycle

\section{Bullet points:}

\section{What's already known about this topic?}

- Female sex hormones have been suggested to play a role in the etiology of cutaneous melanoma (CM) and some epidemiological studies suggest that estrogen increase the risk of $\mathrm{CM}$.

- The association with endogenous sex hormones have been studied through various reproductive factors, and parity, age at menarche, age at first birth and length of ovulatory life have been found to be associated with the risk of CM.

\section{What does this study add?}

- In this large nationwide population-based study of the association between reproductive factors and $\mathrm{CM}$ risk with detailed exposure and confounder information, no reproductive factors were clearly associated with CM risk.

- Association between reproductive factors and histological subtypes and anatomical sites are scarcely described in the literature. We observed significant heterogeneity in the effect of length of ovulatory life on the risk of superficial spreading melanoma and nodular melanoma.

This article is protected by copyright. All rights reserved. 


\section{Summary}

\section{Background}

The association between reproductive factors and risk of cutaneous melanoma (CM) is unclear. We investigated this issue in the Norwegian Women and Cancer (NOWAC) cohort study.

\section{Objectives}

To examine the association between the reproductive factors age at menarche, menstrual cycle length, parity, age at first and last birth, menopausal status, breastfeeding duration and length of ovulatory life and CM risk, overall and by histological subtypes and anatomical site

\section{Methods}

We followed 165,712 women aged 30-75 at inclusion from 1991-2007 to the end of 2015 . Multivariable Cox regression was used to estimate hazard ratios (HRs) with $95 \%$ confidence intervals (Cls).

\section{Results}

The mean age at cohort enrolment was 49 years. During a median follow-up of 18 years, 1,347 CM cases were identified. No reproductive factors were clearly associated with $\mathrm{CM}$ risk. When stratifying by histological subtype we observed significant heterogeneity $(p=0.01)$ in the effect of length of ovulatory life on the risk of superficial spreading melanoma (HR 1.02, 95\% Cl 1.01-1.04 per year increase) and nodular melanoma (HR 0.97, 95\% Cl 0.94-1.01 per year increase). When stratifying by

This article is protected by copyright. All rights reserved. 
anatomical site, menopausal status ( $\mathrm{HR} 0.54,95 \% \mathrm{Cl} 0.31-0.92$, postmenopausal compared to premenopausal) and menstrual cycle length ( $\mathrm{HR} 1.07,95 \% \mathrm{Cl} 1.01-1.13$, per day increase) were associated with $\mathrm{CM}$ of the trunk, and significant heterogeneity between anatomical sites was observed for menopausal status $(p=0.04)$.

\section{Conclusions}

In this large population-based Norwegian cohort study, we did not find convincing evidence of an association between reproductive factors and risk of CM.

\section{Introduction}

The incidence of cutaneous melanoma (CM) is rising in Caucasian populations, despite recent improvements in prevention and diagnosis (1). In 2012 CM was estimated to account for 232,000 new cancer cases and 55,000 deaths worldwide (2).

Exposure to solar ultraviolet (UV) radiation and indoor tanning, having a fair skin complexion, presence of many nevi and freckles, light hair, and skin reaction to the sun are important $\mathrm{CM}$ risk factors $(3,4)$. Female sex hormones, both endogenous and exogenous, have also been suggested to play a role in the etiology of $\mathrm{CM}$. The fact that a better $\mathrm{CM}$ prognosis is observed in females than in males, and that the incidence of $\mathrm{CM}$ is higher among women than men between the age of 20 and 45 years, but that an opposite trend is observed after the age of 50 suggests that female sex hormones might influence $\mathrm{CM}$ development and prognosis $(5,6)$. The association between female sex hormones and risk of $\mathrm{CM}$ is biologically plausible as both estrogen receptors $\alpha, \beta$ and the nonstandard G protein-coupled estrogen receptor, as well as progesterone receptors, are found in $\mathrm{CM}$ tissue $(7,8)$. Some in vitro experiments suggested that estrogen might increase proliferation of 
melanocytes and $\mathrm{CM}$ cells, while progesterone possibly acts as an anti-proliferative and proapoptotic agent (8-12).

A large Dutch case-control study found a strong detrimental effect of oral contraceptives (OC) and unopposed estrogen hormone therapy (HT) on CM risk (13). In a large cohort study from Norway on $\mathrm{HT}$, estrogen was positively associated with CM risk, while progestin seemed to be protective of CM (14). However, a meta-analysis of epidemiological studies up to 2009 found no association between HT or OC and CM risk (15). The meta-analysis did, however, find age at first birth to be positively associated with $\mathrm{CM}$ risk (i.e. the older the age the higher the risk), and parity to be inversely associated with CM risk. Additionally, did and a large Swedish case-control study report both parity and early childbearing to be protective of $\mathrm{CM}$, although personal UV exposure was not adjusted for (16). A large French cohort study from 2011 found late age at menarche, early natural menopause and shorter ovulatory life to be associated with lower risk of CM (17).

Overall, the association between female sex hormones and CM risk is still controversial, and there has been little focus on hormones in relation to CM histological subtypes and anatomical sites relating to the divergent pathways hypothesis (18). We studied the association between the reproductive factors age at menarche, menstrual cycle length, parity, age at first and last birth, menopausal status, breastfeeding duration and length of ovulatory life, and risk of CM overall and by histological subtype and anatomical site in a large nationwide population-based cohort.

This article is protected by copyright. All rights reserved. 


\section{Material and methods}

\section{Data source}

The Norwegian Women and Cancer (NOWAC) cohort was established in 1991 as a large nationwide population-based cohort in Norway. Cohort characteristics of NOWAC have been described in detail elsewhere (19). Briefly, invitation letters were sent to random samples of in total 327,476 women aged 30-75 in 1991-2007 with a response rate of 53\%. Women who answered the baseline questionnaire were sent follow-up questionnaires every 4-6 years (response $80 \%$ for the second and $79 \%$ for third questionnaire). Follow-up was evaluated by linkage to the Cancer Registry of Norway for information on cancer diagnosis and vital status.

In total, we included 172,478 women answering the baseline questionnaire. We excluded women with a cancer diagnosis other than non-melanoma skin cancer prior to inclusion $(n=6,694)$ and date of death or emigration prior to inclusion ( $n=72$ ), resulting in a final sample size of $n=165,712$ (Fig. 1).

\section{Exposure and outcome}

Participants were asked about their reproductive history in the baseline and follow-up questionnaires. The exposures of interest were age at menarche $(\leq 11,12,13,14$ or $\geq 15$ years), menstrual cycle length during midlife defined as number of days between the first day of menstruating in two consecutive cycles $(<25,25-30$ or $>30$ days), parity (including stillbirths) $(0,1,2$, 3 or $\geq 4$ children), age at first birth $(<22,22-23,24-26$ or $\geq 27$ years $)$, age at last birth $(<26,26-28,29-$ 32 or $\geq 33$ years), total breastfeeding duration (0, 1-4, 5-9, 10-16 or $\geq 17$ months) and menopausal status (premenopausal, postmenopausal), defined based on the question "How old were you when the menstruation ceased?". Women with missing information on age at menopause (37\%) were coded as menopausal at age 53, which is the cutoff used in the Million Women Study (20) and the

This article is protected by copyright. All rights reserved. 
validity has been demonstrated in a previous NOWAC publication (21). Length of ovulatory life was calculated as the age difference between menopause and menarche subtracting 9 months for each pregnancy, and categorized according to quartiles.

The outcome was incident CM using the Cancer Registry of Norway modified version of the International Classification of Diseases $7^{\text {th }}$ revision (ICD-7 codes 1900-1909). Anatomical site was defined as head/neck (190.0), trunk (190.1/190.7), upper limbs (190.2) and lower limbs (190.3/190.4). Histological subtype was defined using ICD-Oncology $3^{\text {rd }}$ edition codes (superficial spreading melanoma $(\mathrm{SSM})=8743.3$ and nodular melanoma $(N M)=8721.3 ;$ other subtypes were too rare to be included).

\section{Covariates}

Region (latitudes $71^{\circ} \mathrm{N}-58^{\circ} \mathrm{N}$ ) of residential ambient UV exposure was categorized according to average number of hours of ambient residential UV exposure (low (northern Norway), medium-low (central Norway), medium (southwestern Norway), highest (southeastern Norway) (22). Birth cohort was categorized in 5-years intervals $(<1940,1940-1944,1945-1949$ and $\geq 1950)$. Body surface area (BSA) $\left(\mathrm{m}^{2}\right)$ was calculated using the DuBois and DuBois' equation (weight ${ }^{0.4253} \mathrm{x}$ height ${ }^{0.7253} \mathrm{x}$ 0.007184 ) and categorized according to quartiles (23). We categorized smoking as (never, past or current), education ( $\leq 10,11-13$ or $>13$ years) and marital status (married/partnered or not married/partnered) at cohort enrolment (baseline). Host pigmentation included untanned skin color (recorded on an $1 \times 9 \mathrm{~cm}$ color scale graded from 1 (very fair) to 10 (very dark); categorized as dark (6-10), medium (4 and 5) or light (1-3)), hair color (black/dark brown, brown, blond/yellow or red) and number of asymmetric nevi $>5$ millimeters on legs $(0,1$ or $\geq 2)$. Lifetime UV exposure until cohort enrolment included mean number of sunburns per year $(0, \leq 1,1-2$ or $>2)$, mean number of weeks per year spent on sunbathing vacation $(0, \leq 1,1-2,2-3$ or $>3)$, and use of indoor tanning devices 
(never, age at initiation $<30$ years or age at initiation $\geq 30$ years). These were calculated according to Ghiasvand et al. $(24,25)$. None of the exposures were adjusted for use of $\mathrm{OC}$ or $\mathrm{HT}$, as adjusting for this did not change the estimated associations.

\section{Statistical analysis}

Hazard ratios (HRs) with 95\% confidence intervals (Cls) were estimated by Cox regression using age as time scale and left truncated at age of first questionnaire. Diagnosis of CM was the event of interest. Women were censored at death, emigration, cancer diagnosis other than $\mathrm{CM}$, except nonmelanoma skin cancer, or end of follow-up (December 31, 2015), whichever occurred first.

Parity and menopausal status were analyzed as time-dependent variables. Age at last birth, duration of breastfeeding and length of ovulatory life were only analyzed among postmenopausal women, starting follow-up at age of menopause. When analyzing age at first and last birth only parous women were included.

All estimates were adjusted for residential ambient UV exposure, birth cohort, host pigmentation (hair color, skin color and large asymmetric nevi) and personal UV exposure (sunburns, bathing vacations and indoor tanning). Additional potential adjustment variables were selected based on simplified directed acyclic graphs for each exposure, and only variables that significantly improved the fit of the model were included.

When analyzing the association of reproductive factors by anatomical site only $\mathrm{CM}$ diagnosis at that specific site was analyzed as event, while $\mathrm{CM}$ in other sites were considered as censoring events. We did the same for histological subtypes. Heterogeneity between histological subtypes and anatomical sites was evaluated by contrast tests (26).

This article is protected by copyright. All rights reserved. 
We performed sensitivity analysis, excluding women with very dark skin (grades 8-10). We also adjusted for birth cohort by stratification (stratified Cox-regression) instead of regular adjustment. In a subgroup of women with available information on use of $O C$ we subtracted years of $O C$ use from the length of ovulatory life measure.

The exposures of interest and covariates had a varying degree of missing values $(0-70 \%)$, see Supplementary table 1 and 2 for details. To assess the influence of missing values we used multiple imputation with chained equations, assuming that the missing values are missing at random (27). The imputation model included the outcome and all exposures and adjustment variables. We imputed 70 data sets and the estimates and standard errors were combined using Rubin's rules (28).

All tests were two sided with a 5\% statistical significance level. Proportionality was assessed with Schoenfeld residuals. All statistical analyses were performed using R version 3.3.3 (http://cran.rproject.org) and the R-package mice, version 2.46.0 was used for multiple imputation (29).

\section{Ethics}

NOWAC has been approved by the Regional Committees for Medical and Health Research and the Norwegian Data Inspectorate. All participants have given written consent.

\section{Results}

We followed 165,712 women from cohort enrolment in 1991-2007 to the end of 2015 . The median follow-up was 18.1 years (range $<1$ to 24.7 years) during which 1,347 incident CM occurred. Characteristics of CM cases and non-cases are described in Table 1.

This article is protected by copyright. All rights reserved. 
The risks of $\mathrm{CM}$ associated with reproductive factors are reported in Table 2. Menarche at age 12 was significantly associated with an increased risk of CM compared to age 13 (HR 1.18, 95\% Cl 1.021.38), but no trend emerged. Menstrual cycle length during midlife, parity, age at first birth, menopausal status, age at last birth and breastfeeding duration were not significantly associated with CM risk.

When separating CM into SSM and NM, significant heterogeneity was found for length of ovulatory life $(p=0.01)$ (Table 3$)$. Length of ovulatory life was significantly positively associated with SSM (HR $1.02,95 \% \mathrm{Cl} 1.00-1.04$, per year increase) and not associated with NM (HR 0.97, 95\% Cl 0.94-1.01).

Table 4 displays the anatomical site-specific results for the reproductive factors. Significant heterogeneity was observed for menopausal status $(p=0.04)$. Postmenopausal women had a significantly lower risk of $\mathrm{CM}$ of the trunk ( $\mathrm{HR} 0.54,95 \% \mathrm{Cl} 0.31-0.92)$ as compared to premenopausal women. In addition, menstrual cycle length during midlife was associated with a significantly increased risk of $\mathrm{CM}$ of the trunk ( $\mathrm{HR} 1.07,95 \% \mathrm{Cl} 1.01-1.13$, per year increase), but with no significant heterogeneity between sites $(p=0.07)$.

As a sensitivity analysis we excluded women with very dark skin $(n=2,491)$ and the results did not change substantially (data not shown). Additionally, when adjusting for birth cohort by stratification the results were similar as with regular adjustment (data not shown). When analyzing length of ovulatory life calculated as the age difference between menopause and menarche subtracting 9 months for each pregnancy and years of $\mathrm{OC}$ use in the subset of women with available $\mathrm{OC}$ information, the results were similar to the analyses with years of OC use not subtracted (data not shown). Multiple imputation generally resulted in very similar estimates to the main analyses (data not shown), but some discrepancies were observed. In particular, the association between menstrual cycle length and $\mathrm{CM}$ of the trunk was no longer statistically significant (HR $1.02,95 \% \mathrm{Cl}$ 0.99-1.04 per year increase).

This article is protected by copyright. All rights reserved. 


\section{Discussion}

In this nationwide population-based cohort we evaluated the association between several reproductive factors and $\mathrm{CM}$ risk. Our results suggest that reproductive factors are not associated with $\mathrm{CM}$ risk. However, we observed some heterogeneity between $\mathrm{CM}$ histological subtypes and between anatomical sites. Each year increase in length of ovulatory life was significantly associated with a $2 \%$ increased risk of SSM, and postmenopausal women were at significantly lower risk of CM of the trunk as compared to premenopausal women.

A number of epidemiological studies have evaluated the association between exogenous female sex hormones and $\mathrm{CM}$, but the associations with use of menopausal hormone therapy $(\mathrm{HT})$ and with oral contraceptives $(\mathrm{OC})$ are still controversial. A large meta-analysis comprising six cohort studies and 19 case-control studies published up to 2009 found no significant associations between either HT or OC (15), and three newer studies found no association (30), an increased risk of HT estrogen and decreased risk of HT progestin (14) and a protective effect of HT/OC use (31), respectively.

Endogenous female sex hormones have been evaluated in a number of epidemiological studies through reproductive factors. The meta-analysis of studies published up to 2009 reported an increased risk of melanoma in women with late age at first birth, but no association with menopausal status, age at menopause, age at menarche, exams for fertility or parity (15). A newer meta-analysis comprising three case-control, three nested case-control and five cohort studies published up to 2014 reported a pooled relative risk of 1.47 (95\% Cl 1.07-2.02) comparing oldest to youngest age at first birth (32). Although there seem to be an association between age at first birth and $\mathrm{CM}$ risk, which is in contrast to our null finding, the hormonal mechanism is questionable as Kaae et al. found similar estimates for age at first birth in males and females in a large Danish study comprising 5,688 CM cases, and suggested life-style factors to be a more likely explanation (33).

This article is protected by copyright. All rights reserved. 
In accordance with the meta-analysis of studies published up to 2009 we did not find a convincing association with age at menarche (15). However, Kvaskoff et al. reported a significantly reduced risk of $\mathrm{CM}$ in women with later age at menarche, and shorter length of ovulatory life (17). The latter is, however, in line with our non-significant association of $1 \%$ increase per 1 year increase in ovulatory life. Our measure of length of ovulatory life did not account for use of $\mathrm{OC}$, however in the sensitivity analysis with years of $\mathrm{OC}$ use subtracted from length of ovulatory life, the result was similar.

The associations between reproductive factors and $\mathrm{CM}$ histology and site are scarcely described in the literature. Kvaskoff et al. reported mainly comparable estimates across CM histology (17). This is in contrast to our findings of opposite associations of length of ovulatory life for SSM and NM, but the number of cases within each histology in Kvaskoff et al. was very low and our estimates are close to 1 and only borderline significant for SMM. Kvaskoff et al. noted a significant heterogeneity for nulliparity between head/neck and trunk, although the individual estimates were not statistically significant. Our results indicate a similar opposite association for head/neck (HR 0.51, 95\% Cl 0.22 1.16) and trunk (HR 1.14, $0.95 \% \mathrm{Cl} 0.85-1.54)$, but with no significant heterogeneity $(\mathrm{p}=0.07)$. We found significant heterogeneity across CM sites for menopausal status, which was not observed in Kvaskoff et al. This heterogeneity may be due to residual confounding by age as $\mathrm{CM}$ on the trunk tend to occur at earlier ages, especially in women (34).

The association between sex hormones and risk of $\mathrm{CM}$ is biologically plausible, but the mechanisms through which they exert they effect are still largely unknown. In-vitro experiments have suggested that estrogen might increase proliferation of melanocytes and CM cells, while progesterone possibly acts as an anti-proliferative and pro-apoptotic agent, counteracting the stimulatory effect of estrogen (8-12), which might explain the large amount of null-findings in the literature. Another possible mechanism is through telomere length, where longer telomeres have been found to increase the risk of melanoma $(35,36)$. Estrogen upregulates telomerase in in-vitro experiments, and

This article is protected by copyright. All rights reserved. 
longer ovulatory life and higher parity have been found to respectively increase and decrease telomere length (37-39).

The major strengths of this study are the representative, nationwide population-based prospective design with a follow-up of up to 25 years, the detailed covariate information and the accurate outcome information through linkage with high quality national registries. The design of the study allows for generalizability of findings to the whole country, and perhaps broader. The major limitation is that all covariates are self-reported, thus some misclassification is likely to have occurred, but it was most probably non-differential, since all the information was collected before $\mathrm{CM}$ diagnosis. We have not adjusted for multiple testing, but it is clear that none of the estimates in the sub analyses, nor the heterogeneity tests, would continue to be significant.

In conclusion, no reproductive factor was clearly associated with CM risk in this nationwide cohort study.

Acknowledgements: We are grateful to the women who participated in the NOWAC study.

\section{References}

1. Karimkhani C, Green AC, Nijsten T, Weinstock MA, Dellavalle RP, Naghavi M, et al. The global burden of melanoma: results from the Global Burden of Disease Study 2015. Br J Dermatol. 2017;177(1):134-40.

2. Ferlay J, Steliarova-Foucher E, Lortet-Tieulent J, Rosso S, Coebergh JW, Comber H, et al. Cancer incidence and mortality patterns in Europe: estimates for 40 countries in 2012. Eur J Cancer. 2013;49(6):1374-403.

3. IARC. Radiation. IARC Monographs on the evaluation of the carcinogenic risks to humans. 2012;100D.

4. Berwick M, Buller DB, Cust A, Gallagher R, Lee TK, Meyskens F, et al. Melanoma Epidemiology and Prevention. In: Kaufman HL, Mehnert JM, editors. Melanoma. Cham: Springer International Publishing; 2016. p. 17-49.

5. Armstrong B, English D. Cutaneous and ocular melanoma. In: Schottenfield D, Fraumeni JF, editors. Cancer epidemiology and prevention. 3rd ed. New York: Oxford Universtiy Press; 2006. p. 1196-229.

6. Joosse A, de Vries E, Eckel R, Nijsten T, Eggermont AMM, Holzel D, et al. Gender Differences in Melanoma Survival: Female Patients Have a Decreased Risk of Metastasis. J Invest Dermatol. 2011;131(3):719-26.

This article is protected by copyright. All rights reserved. 
7. Ramelyte E, Koelblinger P, Dummer R. Oestrogen receptor expression in melanoma. J Eur Acad Dermatol Venereol. 2017;31(9):1399-400.

8. Shchelkunova TA, Morozov IA. Progestins and Carcinogenesis. Mol Biol. 2016;50(1):7-21.

9. Wiedemann C, Nagele U, Schramm G, Berking C. Inhibitory effects of progestogens on the estrogen stimulation of melanocytes in vitro. Contraception. 2009;80(3):292-8.

10. Leder DC, Brown JR, Ramaraj P. In-vitro rescue and recovery studies of human melanoma (BLM) cell growth, adhesion and migration functions after treatment with progesterone. International Journal of Clinical and Experimental Medicine. 2015;8(8):12275-85.

11. Ramaraj $\mathrm{P}, \mathrm{Cox} \mathrm{JL}$. In vitro effect of progesterone on human melanoma (BLM) cell growth. International Journal of Clinical and Experimental Medicine. 2014;7(11):3941-53.

12. Fang XF, Zhang XX, Zhou M, Li JW. Effects of Progesterone on the Growth Regulation in Classical Progesterone Receptor-negative Malignant Melanoma Cells. J Huazhong Univ Sci Tech-Med. 2010;30(2):231-4.

13. Koomen ER, Joosse A, Herings RMC, Casparie MK, Guchelaar HJ, Nijsten T. Estrogens, oral contraceptives and hormonal replacement therapy increase the incidence of cutaneous melanoma: a population-based case-control study. Ann Oncol. 2009;20(2):358-64.

14. Botteri E, Stoer NC, Sakshaug S, Graff-Iversen S, Vangen S, Hofvind S, et al. Menopausal hormone therapy and risk of melanoma: Do estrogens and progestins have a different role? Int J Cancer. 2017;141(9):1763-70.

15. Gandini S, lodice S, Koomen E, Di Pietro A, Sera F, Caini S. Hormonal and reproductive factors in relation to melanoma in women: Current review and meta-analysis. Eur J Cancer. 2011;47(17):2607-17.

16. Lambe $M$, Thorn $M$, Sparen $P$, Bergstrom R, Adami HO. Malignant melanoma: reduced risk associated with early childbearing and multiparity. Melanoma Res. 1996;6(2):147-53.

17. Kvaskoff M, Bijon A, Mesrine S, Boutron-Ruault MC, Clavel-Chapelon F. Cutaneous Melanoma and Endogenous Hormonal Factors: A Large French Prospective Study. Am J Epidemiol. 2011;173(10):1192-202.

18. Whiteman DC, Watt P, Purdie DM, Hughes MC, Hayward NK, Green AC. Melanocytic nevi, solar keratoses, and divergent pathways to cutaneous melanoma. J Natl Cancer Inst. 2003;95(11):806-12.

19. Lund E, Dumeaux V, Braaten T, Hjartaker A, Engeset D, Skeie G, et al. Cohort profile: The Norwegian Women and Cancer Study--NOWAC--Kvinner og kreft. Int J Epidemiol. 2008;37(1):36-41.

20. Banks E, Beral V, Bull D, Reeves G, Austoker J, English R, et al. Breast cancer and hormonereplacement therapy in the Million Women Study. Lancet. 2003;362(9382):419-27.

21. Waaseth M, Bakken K, Dumeaux V, Olsen KS, Rylander C, Figenschau Y, et al. Hormone replacement therapy use and plasma levels of sex hormones in the Norwegian Women and Cancer Postgenome Cohort - a cross-sectional analysis. BMC Women's Health. 2008;8(1):1.

22. Ghiasvand R, Lund E, Edvardsen K, Weiderpass E, Veierod MB. Prevalence and trends of sunscreen use and sunburn among Norwegian women. Br J Dermatol. 2015;172(2):475-83.

23. Lentner C. Geigy Scientific Tables Vol 1: units of measurement, body fluids, composition of the body, nutrition. West Caldwell, NJ CIBA-Geigy Corporation 1981.

24. Ghiasvand R, Rueegg CS, Weiderpass E, Green AC, Lund E, Veierod MB. Indoor Tanning and Melanoma Risk: Long-Term Evidence From a Prospective Population-Based Cohort Study. Am J Epidemiol. 2017;185(3):147-56.

25. Ghiasvand R, Weiderpass E, Green AC, Lund E, Veierod MB. Sunscreen Use and Subsequent Melanoma Risk: A Population-Based Cohort Study. J Clin Oncol. 2016;34(33):3976-83.

26. Wang M, Spiegelman D, Kuchiba A, Lochhead P, Kim S, Chan AT, et al. Statistical Methods for Studying Disease Subtype Heterogeneity. Statistics in medicine. 2016;35(5):782-800.

27. Bartlett JW, Seaman SR, White IR, Carpenter JR. Multiple imputation of covariates by fully conditional specification: Accommodating the substantive model. Statistical methods in medical research. 2015;24(4):462-87.

This article is protected by copyright. All rights reserved. 
28. Rubin D. Multiple Imputation for Nonresponse in Surveys. New York: John Wiley and Sons; 2004.

29. van Buuren S, Groothuis-Oudshoorn K. mice: Multivariate Imputation by Chained Equations in R. Journal of Statistical Software. 2011;43(3):1-67.

30. Tang JY, Spaunhurst KM, Chlebowski RT, Wactawski-Wende J, Keiser E, Thomas F, et al. Menopausal hormone therapy and risks of melanoma and nonmelanoma skin cancers: women's health initiative randomized trials. J Natl Cancer Inst. 2011;103(19):1469-75.

31. De Giorgi V, Gori A, Savarese I, D'Errico A, Scarfi F, Papi F, et al. Role of BMI and hormone therapy in melanoma risk: a case-control study. J Cancer Res Clin Oncol. 2017;143(7):1191-7.

32. Li ZG, M.; Cen, Y. Age at first birth and melanoma risk: a meta-analysis. International Journal of Clinical and Experimental Medicine. 2014;7(12):5201-9.

33. Kaae J, Andersen A, Boyd HA, Wohlfahrt J, Melbye M. Reproductive history and cutaneous malignant melanoma: a comparison between women and men. Am J Epidemiol. 2007;165(11):126570.

34. Whiteman DC, Stickley M, Watt P, Hughes MC, Davis MB, Green AC. Anatomic site, sun exposure, and risk of cutaneous melanoma. J Clin Oncol. 2006;24(19):3172-7.

35. Nan H, Du M, De Vivo I, Manson JE, Liu S, McTiernan A, et al. Shorter telomeres associate with a reduced risk of melanoma development. Cancer research. 2011;71(21):6758-63.

36. Rachakonda S, Kong H, Srinivas N, Garcia-Casado Z, Requena C, Fallah M, et al. Telomere length, telomerase reverse transcriptase promoter mutations, and melanoma risk. Genes, chromosomes \& cancer. 2018;57(11):564-72.

37. Pines A. Telomere length and telomerase activity in the context of menopause. Climacteric : the journal of the International Menopause Society. 2013;16(6):629-31.

38. Lin J, Kroenke CH, Epel E, Kenna HA, Wolkowitz OM, Blackburn E, et al. Greater endogenous estrogen exposure is associated with longer telomeres in postmenopausal women at risk for cognitive decline. Brain research. 2011;1379:224-31.

39. Pollack AZ, Rivers K, Ahrens KA. Parity associated with telomere length among US reproductive age women. Hum Reprod. 2018;33(4):736-44.

\section{Figure legends}

Figure 1. Flowchart of study participants: The NOWAC Study.

This article is protected by copyright. All rights reserved. 
Table 1. Baseline characteristics of the study participants and association with melanoma risk: The NOWAC Study.

\begin{tabular}{|c|c|c|}
\hline & \multicolumn{2}{|c|}{ Incident melanoma } \\
\hline & $\begin{array}{l}\text { Yes } \\
\text { N (\%) }\end{array}$ & $\begin{array}{l}\text { No } \\
\text { N (\%) }\end{array}$ \\
\hline Age in years $^{\mathrm{a}}$ & $48(43,56)$ & $49(43,56)$ \\
\hline \multicolumn{3}{|l|}{ Birth cohort, $n=165712$} \\
\hline$<1940$ & $137(10)$ & $14458(9)$ \\
\hline $1940-1944$ & $234(17)$ & $20605(13)$ \\
\hline $1945-1949$ & $408(30)$ & $47248(29)$ \\
\hline$\geq 1950$ & $568(42)$ & $82054(50)$ \\
\hline \multicolumn{3}{|l|}{ Education, $n=157008$} \\
\hline$\leq 10$ years & $412(32)$ & $55733(36)$ \\
\hline $11-13$ years & $416(33)$ & $45990(30)$ \\
\hline$>13$ years & $448(35)$ & $54009(35)$ \\
\hline \multicolumn{3}{|l|}{ Marital status, n= 160129} \\
\hline Married/partnered & $1056(81)$ & $126253(79)$ \\
\hline Not married/partnered & $247(19)$ & $32573(21)$ \\
\hline \multicolumn{3}{|l|}{ Smoking status, n= 164914} \\
\hline Never & $576(43)$ & $57772(35)$ \\
\hline Past & $456(34)$ & $56084(34)$ \\
\hline Current & $305(23)$ & $49721(30)$ \\
\hline \multicolumn{3}{|l|}{ Body surface area, 161590} \\
\hline $\mathrm{Q} 1:<1.65 \mathrm{~m}^{2}$ & $282(21)$ & $39933(25)$ \\
\hline Q2: $1.65-1.73 \mathrm{~m}^{2}$ & $324(25)$ & $40148(25)$ \\
\hline Q3: $1.74-1.83 \mathrm{~m}^{2}$ & $385(29)$ & $40000(25)$ \\
\hline $\mathrm{Q} 4: \geq 1.83 \mathrm{~m}^{2}$ & $324(25)$ & $40194(25)$ \\
\hline \multicolumn{3}{|l|}{ Hair color, $n=151700$} \\
\hline Black/dark brown & $137(11)$ & $26231(17)$ \\
\hline Brown & $382(31)$ & $60404(40)$ \\
\hline Blond/yellow & $623(51)$ & $59193(39)$ \\
\hline Red & $88(7)$ & $4642(3)$ \\
\hline \multicolumn{3}{|l|}{ Skin color, $n=131261$} \\
\hline Very dark/dark & $189(18)$ & $28325(22)$ \\
\hline Medium & $379(35)$ & $49181(38)$ \\
\hline Light & $503(47)$ & $52684(40)$ \\
\hline \multicolumn{3}{|c|}{$\begin{array}{l}\text { Total no. of asymmetrical nevi with diameter }>5 \\
\mathrm{~mm} \text { on legs, } n=145641\end{array}$} \\
\hline 0 & $891(76)$ & $127617(88)$ \\
\hline 1 & $12611)$ & $9713(7)$ \\
\hline$\geq 2$ & $154(13)$ & $7140(5)$ \\
\hline \multicolumn{3}{|c|}{ Residential ambient UV exposure $n=165712$} \\
\hline Low (northern Norway) & $144(11)$ & $35788(22)$ \\
\hline Medium-low (central Norway) & $161(12)$ & $18426(11)$ \\
\hline Medium(southwestern Norway) & $279(21)$ & $30562(19)$ \\
\hline Highest (southeastern Norway) & $763(57)$ & $79589(48)$ \\
\hline \multicolumn{3}{|c|}{ Mean sunburns per year, $n=122083$} \\
\hline 0 & $90(9)$ & $17744(15)$ \\
\hline$\leq 1$ & $612(60)$ & $74975(62)$ \\
\hline
\end{tabular}

This article is protected by copyright. All rights reserved. 


\begin{tabular}{|l|l|l|}
\hline$>1-2$ & $230(22)$ & $21280(18)$ \\
$>2$ & $93(9)$ & $7059(6)$ \\
\hline $\begin{array}{l}\text { Mean weeks of sunbathing vacations per year, } \\
\mathbf{n}=\mathbf{1 3 0} \mathbf{7 2 3}\end{array}$ & & \\
0 & $129(12)$ & $16713(13)$ \\
$\leq 1$ & $300(28)$ & $38454(30)$ \\
$>1-2$ & $352(33)$ & $42475(33)$ \\
$>2-3$ & $157(15)$ & $18760(14)$ \\
$>3$ & $136(13)$ & $13247(10)$ \\
\hline Indoor tanning, $\mathbf{n}=131 \mathbf{1 3 5}$ & & \\
\hline Never & $381(35)$ & $45129(35)$ \\
\hline Age at initiation $<30$ years & $160(15)$ & $20790(16)$ \\
Age at initiation $\geq 30$ years & $555(51)$ & $64120(49)$ \\
\hline
\end{tabular}

${ }^{a}$ Median (interquartile range.

This article is protected by copyright. All rights reserved. 
Table 2. Reproductive factors and risk of melanoma: The NOWAC Study.

\begin{tabular}{|c|c|c|c|}
\hline & No. of cases & Person years & $\mathrm{HR}^{\mathrm{a}}(95 \% \mathrm{Cl})$ \\
\hline \multicolumn{4}{|c|}{ Age at menarche, $n=162,881$} \\
\hline$\leq 11$ years & 99 & 234,772 & $0.87(0.70-1.09)$ \\
\hline 12 years & 295 & 514,209 & $1.18(1.02-1.38)$ \\
\hline 13 years & 368 & 749,315 & Ref. \\
\hline 14 years & 326 & 665,886 & $0.97(0.84-1.13)$ \\
\hline$\geq 15$ years & 236 & 483,364 & $0.94(0.80-1.11)$ \\
\hline Per year & 1324 & & $0.98(0.94-1.02)$ \\
\hline \multicolumn{4}{|c|}{$\begin{array}{l}\text { Menstrual cycle length during midlife, } \\
n=47,880\end{array}$} \\
\hline$<25$ days & 63 & 141,304 & $0.96(0.74-1.26)$ \\
\hline $25-30$ days & 421 & 896,872 & Ref. \\
\hline$>30$ days & 20 & 49,273 & $0.86(0.55-1.35)$ \\
\hline Per day & 504 & & $1.01(0.98-1.04)$ \\
\hline \multicolumn{4}{|c|}{ Parity ${ }^{c, i}, n=165,712$} \\
\hline 0 children & 127 & 248,316 & Ref. \\
\hline 1 child & 134 & 312,595 & $0.90(0.70-1.14)$ \\
\hline 2 children & 580 & $1,123,020$ & $1.06(0.88-1.29)$ \\
\hline 3 children & 366 & 707,996 & $1.11(0.91-1.37)$ \\
\hline$\geq 4$ children & 140 & 302,388 & $1.04(0.81-1.33)$ \\
\hline Per child & 1347 & & $1.03(0.98-1.08)$ \\
\hline \multicolumn{4}{|c|}{ Nulliparous $^{\mathrm{c}, \mathrm{i}}, \mathrm{n}=165,712$} \\
\hline No & 1220 & $2,445,998$ & Ref. \\
\hline Yes & 127 & 248,316 & $0.95(0.79-1.14)$ \\
\hline \multicolumn{4}{|c|}{ Age at first birth ${ }^{\mathrm{c}, \mathrm{f}}, \mathrm{n}=149,863$} \\
\hline$<22$ years & 373 & 805,770 & Ref. \\
\hline $22-23$ years & 234 & 474,191 & $0.96(0.81-1.13)$ \\
\hline $24-26$ years & 310 & 571,500 & $1.00(0.86-1.17)$ \\
\hline$\geq 27$ years & 303 & 594,450 & $0.94(0.80-1.11)$ \\
\hline Per year & 1220 & & $0.99(0.98-1.01)$ \\
\hline \multicolumn{4}{|c|}{ Menopausal status ${ }^{\mathrm{d}, \mathrm{i}}, \mathrm{n}=165,712$} \\
\hline Pre & 226 & 752,486 & Ref. \\
\hline Post & 1,120 & $1,938,493$ & $0.83(0.62-1.13)$ \\
\hline \multicolumn{4}{|c|}{ Age at last birth ${ }^{c, h}, n=127,350$} \\
\hline$<26$ years & 235 & 406,030 & Ref. \\
\hline $26-28$ years & 223 & 372,334 & $0.97(0.81-1.17)$ \\
\hline $29-32$ years & 282 & 480,843 & $0.94(0.79-1.12)$ \\
\hline$\geq 33$ years & 274 & 504,874 & $0.88(0.73-1.06)$ \\
\hline Per year & 1013 & & $0.99(0.98-1.00)$ \\
\hline \multicolumn{4}{|c|}{ Breastfeeding duration $^{\mathrm{e}, \mathrm{g}}, \mathrm{n}=85,406$} \\
\hline 0 months & 49 & 77,782 & $1.17(0.85-1.62)$ \\
\hline $1-4$ months & 101 & 213,166 & $0.93(0.72-1.20)$ \\
\hline $5-9$ months & 145 & 279,902 & Ref. \\
\hline $10-16$ months & 165 & 274,857 & $1.14(0.91-1.42)$ \\
\hline$\geq 17$ months & 194 & 340,141 & $1.07(0.86-1.33)$ \\
\hline Per month & 654 & & $1.00(0.99-1.01)$ \\
\hline \multicolumn{4}{|c|}{ Length of ovulatory life $e^{\mathrm{b}, \mathrm{g}}, \mathrm{n}=142,611$} \\
\hline Q1: $<33.5$ years & 267 & 457,714 & $0.95(0.80-1.12)$ \\
\hline
\end{tabular}

This article is protected by copyright. All rights reserved. 


\begin{tabular}{|l|l|l|l|}
\hline Q2: $33.5-36.5$ years & 268 & 531,090 & Ref. \\
\hline Q3: $36.6-38.4$ years & 224 & 378,113 & $0.99(0.83-1.19)$ \\
Q4: $\geq 38.5$ years & 212 & 349,846 & $1.03(0.86-1.24)$ \\
\hline Per year & 971 & & $1.01(0.99-1.02)$ \\
\hline
\end{tabular}

${ }^{a}$ Hazard ratios (HRs) and 95\% confidence intervals (Cls) from Cox regression with age as the time scale (age adjusted) and adjusted for residential ambient ultraviolet (UV) exposure, birth cohort, host pigmentation (hair color, skin color and large asymmetric nevi) and UV exposure (sunburns, bathing vacations and solarium use). ${ }^{b}$ Additionally adjusted for body surface area (BSA) and smoking. ${ }^{c}$ Additionally adjusted for education. ${ }^{d}$ Additionally adjusted for BSA, smoking and education.

${ }^{\mathrm{e}}$ Additionally adjusted for marital status and smoking. ${ }^{\mathrm{f}}$ Only in parous women. ${ }^{\mathrm{g}}$ Only in postmenopausal women. ${ }^{\text {h}}$ Only in parous postmenopausal women. 'Analysed as time-dependent.

This article is protected by copyright. All rights reserved. 
Table 3. Reproductive factors and risk of melanoma by histological subtype: The NOWAC Study.

\begin{tabular}{|c|c|c|c|c|c|}
\hline & \multicolumn{2}{|c|}{$\begin{array}{l}\text { Superficial spreading } \\
\text { melanoma }\end{array}$} & \multicolumn{2}{|c|}{ Nodular melanoma } & \multirow[b]{2}{*}{$p$ for heterogeneity } \\
\hline & $\begin{array}{l}\text { No. of } \\
\text { cases }\end{array}$ & $\mathrm{HR}^{\mathrm{a}}(95 \% \mathrm{Cl})$ & $\begin{array}{l}\text { No. of } \\
\text { cases }\end{array}$ & $\mathrm{HR}^{\mathrm{a}}(95 \% \mathrm{Cl})$ & \\
\hline \multicolumn{6}{|c|}{ Age at menarche, $n=162,881$} \\
\hline$\leq 11$ years & 58 & $0.86(0.65-1.16)$ & 17 & $1.01(0.59-1.75)$ & \\
\hline 12 years & 190 & $1.30(1.07-1.58)$ & 38 & $1.02(0.68-1.54)$ & \\
\hline 13 years & 215 & Ref. & 55 & Ref. & \\
\hline 14 years & 199 & $1.03(0.85-1.25)$ & 43 & $0.85(0.57-1.27)$ & \\
\hline$\geq 15$ years & 144 & $1.01(0.81-1.24)$ & 36 & $0.93(0.61-1.42)$ & \\
\hline Per year & 806 & $0.98(0.93-1.03)$ & 189 & $0.96(0.87-1.07)$ & 0.76 \\
\hline \multicolumn{6}{|c|}{$\begin{array}{l}\text { Menstrual cycle length during midlife }{ }^{b}, \\
n=47,880\end{array}$} \\
\hline$<25$ days & 35 & $0.86(0.60-1.22)$ & 10 & $1.01(0.52-1.97)$ & \\
\hline $25-30$ days & 264 & Ref. & 62 & Ref. & \\
\hline$>30$ days & 14 & $0.96(0.56-1.63)$ & 4 & $1.20(0.43-3.30)$ & \\
\hline Per day & 313 & $1.02(0.99-1.07)$ & 76 & $1.04(0.96-1.13)$ & 0.77 \\
\hline \multicolumn{6}{|c|}{ Parity $^{c, i}, n=165,712$} \\
\hline 0 children & 80 & Ref. & 19 & Ref. & \\
\hline 1 child & 84 & $0.88(0.65-1.19)$ & 10 & $0.46(0.21-0.99)$ & \\
\hline 2 children & 357 & $1.03(0.81-1.31)$ & 93 & $1.19(0.73-1.96)$ & \\
\hline 3 children & 208 & $1.02(0.79-1.32)$ & 48 & $0.98(0.57-1.67)$ & \\
\hline$\geq 4$ children & 92 & $1.16(0.86-1.58)$ & 21 & $0.92(0.49-1.74)$ & \\
\hline Per child & 821 & $1.04(0.98-1.10)$ & 191 & $1.02(0.90-1.14)$ & 0.73 \\
\hline \multicolumn{6}{|c|}{ Nulliparous $^{\mathrm{c}, \mathrm{i}}, \mathrm{n}=165,712$} \\
\hline No & 741 & Ref. & 172 & Ref. & \\
\hline Yes & 80 & $0.98(0.78-1.24)$ & 19 & $1.00(0.62-1.61)$ & 0.95 \\
\hline \multicolumn{6}{|c|}{ Age at first birth ${ }^{c, f}, n=149,863$} \\
\hline$<22$ years & 222 & Ref. & 54 & Ref. & \\
\hline $22-23$ years & 152 & $1.05(0.85-1.29)$ & 30 & $0.89(0.57-1.40)$ & \\
\hline $24-26$ years & 189 & $1.02(0.83-1.25)$ & 45 & $1.09(0.72-1.65)$ & \\
\hline$\geq 27$ years & 178 & $0.92(0.74-1.13)$ & 43 & $1.03(0.67-1.59)$ & \\
\hline
\end{tabular}

This article is protected by copyright. All rights reserved. 


\begin{tabular}{|c|c|c|c|c|c|}
\hline Per year & 741 & $0.99(0.98-1.01)$ & 172 & $0.99(0.96-1.03)$ & 0.96 \\
\hline \multicolumn{6}{|c|}{ Menopausal status ${ }^{\mathrm{d}, \mathrm{i}}, \mathrm{n}=165,712$} \\
\hline Pre & 164 & & 26 & Ref. & \\
\hline Post & 656 & $0.72(0.49-1.06)$ & 165 & $1.22(0.54-2.78)$ & 0.25 \\
\hline \multicolumn{6}{|c|}{ Age at last birth ${ }^{\mathrm{c}, \mathrm{h}}, \mathrm{n}=127,350$} \\
\hline$<26$ years & 136 & Ref. & 34 & Ref. & \\
\hline $26-28$ years & 128 & $0.98(0.77-1.25)$ & 37 & $1.10(0.69-1.77)$ & \\
\hline $29-32$ years & 158 & $0.93(0.74-1.18)$ & 44 & $1.01(0.64-1.59)$ & \\
\hline$\geq 33$ years & 169 & $0.98(0.77-1.24)$ & 32 & $0.70(0.42-1.16)$ & \\
\hline Per year & 591 & $1.00(0.98-1.02)$ & 147 & $0.98(0.94-1.01)$ & 0.24 \\
\hline \multicolumn{6}{|c|}{ Breastfeeding duration $^{\mathrm{e}, \mathrm{g}}, \mathrm{n}=85,406$} \\
\hline 0 months & 29 & $1.28(0.83-1.96)$ & 8 & $1.15(0.51-2.56)$ & \\
\hline $1-4$ months & 61 & $1.02(0.73-1.43)$ & 15 & $0.84(0.44-1.60)$ & \\
\hline $5-9$ months & 79 & Ref. & 24 & Ref. & \\
\hline $10-16$ months & 91 & $1.15(0.85-1.55)$ & 27 & $1.15(0.66-1.99)$ & \\
\hline$\geq 17$ months & 110 & $1.11(0.83-1.49)$ & 28 & $0.98(0.56-1.70)$ & \\
\hline Per month & 370 & $1.00(0.99-1.01)$ & 102 & $1.00(0.98-1.01)$ & 0.69 \\
\hline \multicolumn{6}{|c|}{ Length of ovulatory life $^{\mathrm{b}, \mathrm{g}}, \mathrm{n}=142,611$} \\
\hline Q1: < 33.5 years & 138 & $0.80(0.63-1.01)$ & 53 & $1.34(0.87-2.08)$ & \\
\hline Q2: $33.5-36.5$ years & 162 & Ref. & 35 & Ref. & \\
\hline Q3: $36.6-38.4$ years & 131 & $0.95(0.75-1.19)$ & 35 & $1.20(0.75-1.93)$ & \\
\hline Q4: $\geq 38.5$ years & 130 & $1.03(0.81-1.30)$ & 23 & $0.87(0.51-1.49)$ & \\
\hline Per year & 561 & $1.02(1.00-1.04)$ & 146 & $0.97(0.94-1.01)$ & 0.01 \\
\hline
\end{tabular}

${ }^{\mathrm{a}} \mathrm{Hazard}$ ratios (HRs) and $95 \%$ confidence intervals (Cls) from Cox regression with age as the time scale (age adjusted) and adjusted for residential ambient ultraviolet (UV) exposure, birth cohort, host pigmentation (hair color, skin color and large asymmetric nevi) and UV exposure (sunburns, bathing vacations and solarium use). ${ }^{b}$ Additionally adjusted for body surface area (BSA) and smoking. 'Additionally adjusted for education. ${ }^{\mathrm{d}}$ Additionally adjusted for BSA, smoking and education. ${ }^{\mathrm{e} A d d i t i o n a l l y ~ a d j u s t e d ~ f o r ~ m a r i t a l ~ s t a t u s ~ a n d ~ s m o k i n g . ~}{ }^{\mathrm{f} O n l y}$ in parous women. ${ }^{\mathrm{g}}$ Only in postmenopausal women. ${ }^{\mathrm{h}}$ Only in parous postmenopausal women. 'Analysed as time-dependent.

This article is protected by copyright. All rights reserved. 
Table 4. Reproductive factors and risk of melanoma by anatomical site: The NOWAC Study.

\begin{tabular}{|c|c|c|c|c|c|c|c|c|c|}
\hline & \multicolumn{2}{|c|}{ Head and neck } & \multicolumn{2}{|c|}{ Upper limbs } & \multicolumn{2}{|l|}{ Trunk } & \multicolumn{3}{|c|}{ Lower limbs } \\
\hline ) & $\begin{array}{l}\text { No. of } \\
\text { cases }\end{array}$ & $\mathrm{HR}(95 \% \mathrm{Cl})$ & $\begin{array}{l}\text { No. of } \\
\text { cases }\end{array}$ & $\mathrm{HR}^{\mathrm{a}}(95 \% \mathrm{Cl})$ & $\begin{array}{l}\text { No. of } \\
\text { cases }\end{array}$ & $\operatorname{HR}^{\mathrm{a}}(95 \% \mathrm{Cl})$ & $\begin{array}{l}\text { No. of } \\
\text { cases }\end{array}$ & $\mathrm{HR}^{\mathrm{a}}(95 \% \mathrm{Cl})$ & $\begin{array}{l}\mathrm{p} \text { for } \\
\text { heterogeneity }\end{array}$ \\
\hline \multicolumn{10}{|l|}{ Age at menarche, $n=162,881$} \\
\hline$\leq 11$ years & 6 & $0.54(0.23-1.27)$ & 18 & $0.94(0.56-1.58)$ & 37 & $1.08(0.74-1.56)$ & 35 & $0.81(0.56-1.18)$ & \\
\hline 12 years & 23 & $0.91(0.54-1.53)$ & 46 & $1.07(0.73-1.56)$ & 98 & $1.32(1.00-1.73)$ & 117 & $1.24(0.97-1.59)$ & \\
\hline 13 years & 38 & Ref. & 64 & Ref. & 110 & Ref. & 138 & Ref. & \\
\hline 14 years & 29 & $0.81(0.50-1.31)$ & 51 & $0.86(0.60-1.25)$ & 110 & $1.11(0.85-1.44)$ & 119 & $0.95(0.75-1.22)$ & \\
\hline$\geq 15$ years & 16 & $0.56(0.31-1.02)$ & 37 & $0.81(0.54-1.22)$ & 85 & $1.16(0.87-1.54)$ & 88 & $0.96(0.74-1.26)$ & \\
\hline Per year & 112 & $0.94(0.82-1.07)$ & 216 & $0.93(0.85-1.03)$ & 440 & $1.00(0.94-1.07)$ & 497 & $0.98(0.92-1.04)$ & 0.63 \\
\hline \multicolumn{10}{|l|}{$\begin{array}{l}\text { Menstrual cycle length during } \\
\text { midlife }{ }^{b}, n=47,880\end{array}$} \\
\hline$<25$ days & 8 & $2.01(0.91-4.44)$ & 7 & $0.66(0.30-1.43)$ & 14 & $0.65(0.37-1.13)$ & 29 & $1.12(0.75-1.66)$ & \\
\hline $25-30$ days & 26 & Ref. & 70 & Ref. & 138 & Ref. & 167 & Ref. & \\
\hline$>30$ days & 0 & & 5 & $1.31(0.53-3.24)$ & 10 & $1.33(0.70-2.52)$ & 4 & $0.43(0.16-1.17)$ & \\
\hline Per day & 34 & $0.94(0.85-1.03)$ & 82 & $1.03(0.95-1.11)$ & 162 & $1.07(1.01-1.13)$ & 200 & $0.99(0.94-1.03)$ & 0.07 \\
\hline \multicolumn{10}{|l|}{ Parity ${ }^{c, i}, n=165,712$} \\
\hline 0 children & 6 & Ref. & 17 & Ref. & 50 & Ref. & 46 & Ref. & \\
\hline 1 child & 11 & $1.74(0.64-4.73)$ & 21 & $1.11(0.59-2.11)$ & 47 & $0.78(0.52-1.16)$ & 48 & $0.87(0.58-1.30)$ & \\
\hline 2 children & 45 & $1.93(0.82-4.53)$ & 96 & $1.38(0.82-2.31)$ & 194 & $0.89(0.65-1.22)$ & 218 & $1.08(0.78-1.48)$ & \\
\hline 3 children & 33 & $2.06(0.86-4.95)$ & 62 & $1.36(0.79-2.34)$ & 108 & $0.85(0.60-1.19)$ & 150 & $1.26(0.91-1.77)$ & \\
\hline$\geq 4$ children & 17 & $2.11(0.82-5.42)$ & 24 & $1.13(0.60-2.12)$ & 50 & $1.02(0.68-1.52)$ & 45 & $0.98(0.64-1.49)$ & \\
\hline Per child & 112 & $1.08(0.94-1.25)$ & 220 & $1.03(0.93-1.15)$ & 449 & $1.02(0.94-1.11)$ & 507 & $1.04(0.96-1.12)$ & 0.92 \\
\hline \multicolumn{10}{|l|}{ Nulliparous, ${ }^{\mathrm{c}, \mathrm{i}}, \mathrm{n}=165,712$} \\
\hline No & 106 & Ref. & 203 & Ref. & 399 & Ref. & 461 & Ref. & \\
\hline Yes & 6 & $0.51(0.22-1.16)$ & 17 & $0.77(0.47-1.26)$ & 50 & $1.14(0.85-1.54)$ & 46 & $0.92(0.68-1.25)$ & 0.22 \\
\hline \multicolumn{10}{|l|}{ Age at first birth ${ }^{c, f}, n=149,863$} \\
\hline$<22$ years & 35 & Ref. & 48 & Ref. & 128 & Ref. & 145 & Ref. & \\
\hline $22-23$ years & 17 & $0.67(0.37-1.20)$ & 53 & $1.62(1.09-2.40)$ & 66 & $0.81(0.60-1.09)$ & 90 & $0.97(0.74-1.26)$ & \\
\hline $24-26$ years & 28 & $0.84(0.50-1.41)$ & 51 & $1.21(0.80-1.82)$ & 103 & $1.00(0.77-1.32)$ & 117 & $1.00(0.77-1.29)$ & \\
\hline$\geq 27$ years & 26 & $0.73(0.42-1.27)$ & 51 & $1.26(0.76-1.78)$ & 102 & $0.97(0.73-1.28)$ & 109 & $0.90(0.69-1.17)$ & \\
\hline Per year & 106 & $0.98(0.94-1.03)$ & & $1.00(0.96-1.03)$ & 399 & $1.00(0.97-1.02)$ & 461 & $0.99(0.96-1.01)$ & 0.86 \\
\hline Menopausal status ${ }^{\mathrm{d}, \mathrm{i}}, \mathrm{n}=165,712$ & & & & & & & & & \\
\hline
\end{tabular}

This article is protected by copyright. All rights reserved. 


\begin{tabular}{|c|c|c|c|c|c|c|c|c|c|}
\hline Pre & 16 & Ref. & 22 & Ref. & |76 & Ref. & 97 & Ref. & \\
\hline Post & 96 & $0.36(0.10-1.26)$ & 198 & $1.70(0.77-3.78)$ & 373 & $0.54(0.31-0.92)$ & 409 & $1.08(0.68-1.71)$ & 0.04 \\
\hline \multicolumn{10}{|c|}{ Age at last birth ${ }^{c, h}, n=127,350$} \\
\hline$<26$ years & 23 & Ref. & 37 & Ref. & 79 & Ref. & 87 & Ref. & \\
\hline $26-28$ years & 14 & $0.57(0.29-1.11)$ & 41 & $1.09(0.69-1.70)$ & 73 & $0.98(0.71-1.35)$ & 83 & $1.00(0.74-1.35)$ & \\
\hline $29-32$ years & 31 & $0.87(0.50-1.51)$ & 52 & $1.00(0.65-1.54)$ & 91 & $0.96(0.71-1.31)$ & 101 & $0.95(0.71-1.27)$ & \\
\hline$\geq 33$ years & 23 & $0.54(0.30-0.99)$ & 54 & $0.94(0.60-1.45)$ & 89 & $0.95(0.69-1.30)$ & 99 & $0.93(0.69-1.26)$ & \\
\hline Per year & 91 & $0.97(0.93-1.02)$ & 184 & $0.98(0.95-1.01)$ & 332 & $1.00(0.98-1.02)$ & 370 & $0.99(0.97-1.01)$ & 0.74 \\
\hline \multicolumn{10}{|c|}{$\begin{array}{l}\text { Breastfeeding duration }^{\mathrm{e}, \mathrm{g}}, \\
n=85,406\end{array}$} \\
\hline 0 months & 8 & $1.78(0.75-4.20)$ & 9 & $1.09(0.52-2.30)$ & 11 & $0.83(0.43-1.61)$ & 19 & $1.35(0.79-2.29)$ & \\
\hline $1-4$ months & 14 & $1.31(0.63-2.73)$ & 17 & $0.79(0.43-1.43)$ & 34 & $0.98(0.63-1.53)$ & 35 & $0.94(0.61-1.45)$ & \\
\hline $5-9$ months & 15 & Ref. & 30 & Ref. & 45 & Ref. & 49 & Ref. & \\
\hline $10-16$ months & 9 & $0.57(0.25-1.31)$ & 31 & $1.01(0.61-1.66)$ & 55 & $1.24(0.84-1.85)$ & 62 & $1.27(0.87-1.85)$ & \\
\hline$\geq 17$ months & 20 & $0.92(0.47-1.81)$ & 39 & $0.98(0.60-1.58)$ & 63 & $1.16(0.79-1.71)$ & 64 & $1.09(0.75-1.59)$ & \\
\hline Per month & 66 & $0.98(0.96-1.01)$ & 126 & $1.00(0.98-1.01)$ & 208 & $1.01(1.00-1.02)$ & 229 & $1.00(0.99-1.01)$ & 0.29 \\
\hline \multicolumn{10}{|c|}{$\begin{array}{l}\text { Length of ovulatory life }{ }^{b, g}, \\
n=142,611\end{array}$} \\
\hline Q1: $<33.5$ years & 22 & $1.10(0.62-1.95)$ & 42 & $0.80(0.52-1.22)$ & 78 & $0.82(0.60-1.11)$ & 111 & $1.07(0.81-1.42)$ & \\
\hline Q2: $33.5-36.5$ years & 26 & Ref. & 47 & Ref. & 94 & Ref. & 96 & Ref. & \\
\hline Q3: $36.6-38.4$ years & 19 & $1.13(0.61-2.10)$ & 43 & $1.17(0.77-1.77)$ & 65 & $0.78(0.60-1.08)$ & 82 & $1.00(0.74-1.35)$ & \\
\hline Q4: $\geq 38.5$ years & 16 & $1.12(0.58-2.16)$ & 38 & $1.16(0.75-1.80)$ & 81 & $1.06(0.78-1.44)$ & 71 & $0.94(0.68-1.28)$ & \\
\hline Per year & 83 & $0.98(0.94-1.03)$ & 170 & $1.03(0.99-1.07)$ & 318 & $1.02(0.99-1.05)$ & 360 & $1.00(0.97-1.02)$ & 0.32 \\
\hline
\end{tabular}

${ }^{a}$ Hazard ratios (HRs) and 95\% confidence intervals (Cls) from Cox regression with age as the time scale (age adjusted) and adjusted for residential ambient ultraviolet (UV) exposure, birth cohort, host pigmentation (hair color, skin color and large asymmetric nevi) and UV exposure (sunburns, bathing vacations and solarium use). ${ }^{b}$ Additionally adjusted for body surface area (BSA) and smoking. ${ }^{\mathrm{c} A d d i t i o n a l l y ~ a d j u s t e d ~ f o r ~ e d u c a t i o n . ~}{ }^{\mathrm{d}}$ Additionally adjusted for BSA, smoking and education. ${ }^{\mathrm{e}}$ Additionally adjusted for marital status and smoking. ${ }^{\mathrm{f}}$ Only in parous women. ${ }^{\mathrm{g}}$ Only in postmenopausal women. ${ }^{\mathrm{h}}$ Only in parous postmenopausal women. 'Analysed as time-dependent.

This article is protected by copyright. All rights reserved. 
172,478 women answered baseline questionnaire

6,694 women with a cancer diagnosis prior to baseline questionnaire exduded

165,784 women free from cancer at time of baseline questionnaire

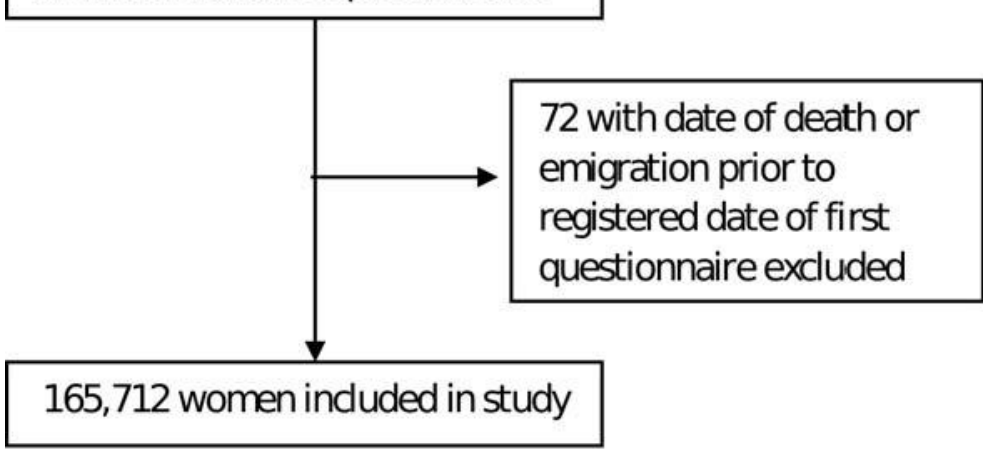

This article is protected by copyright. All rights reserved. 